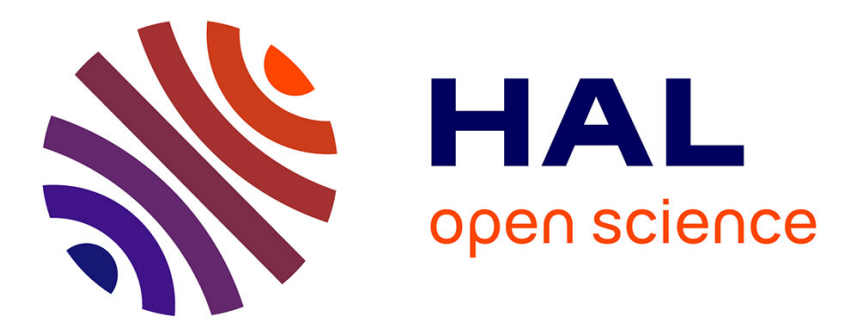

\title{
Non thermal plasma in liquid media: Effect on inulin depolymerization and functionalization
}

Raluca Nastase, Elodie Fourre, Mathieu Fanuel, Xavier Falourd, Isabelle

Capron

\section{- To cite this version:}

Raluca Nastase, Elodie Fourre, Mathieu Fanuel, Xavier Falourd, Isabelle Capron. Non thermal plasma in liquid media: Effect on inulin depolymerization and functionalization. Carbohydrate Polymers, 2020, 231, pp.115704. 10.1016/j.carbpol.2019.115704 . hal-02944380

\author{
HAL Id: hal-02944380 \\ https://hal.inrae.fr/hal-02944380
}

Submitted on 27 Nov 2020

HAL is a multi-disciplinary open access archive for the deposit and dissemination of scientific research documents, whether they are published or not. The documents may come from teaching and research institutions in France or abroad, or from public or private research centers.
L'archive ouverte pluridisciplinaire HAL, est destinée au dépôt et à la diffusion de documents scientifiques de niveau recherche, publiés ou non, émanant des établissements d'enseignement et de recherche français ou étrangers, des laboratoires publics ou privés.

\section{(ㅇ)(1) $\$$}

Distributed under a Creative Commons Attribution - NonCommercial - NoDerivatives| 4.0 
1 Non thermal plasma in liquid media: effect on inulin depolymerization and 2 functionalization

Raluca Nastase ${ }^{1,2}$, Elodie Fourré ${ }^{1}$, Mathieu Fanuel ${ }^{2}$, Xavier Falourd ${ }^{2}$, Isabelle Capron ${ }^{2}$

${ }^{I}$ Research unit on catalysis and unconventional media, IC2MP, Poitiers, France

${ }^{2}$ UR1268 Research unit Biopolymers, interactions and assemblies (BIA), INRA, Nantes, France

Corresponding author: elodie.fourre@univ-poitiers.fr

\section{$\underline{\text { Keywords }}$}

Gas-liquid plasma reactor; non thermal plasma; inulin; depolymerization; infrared spectroscopy; ssNMR spectroscopy

$\underline{\text { Highlights }}$

- A novel double dielectric barrier discharge plasma reactor with a liquid interface has been designed

- It is possible to totally convert inulin into $100 \%$ fructose and glucose

- No degradation products are generated

- Combined analytical results evidenced the acidic attack of the glycosidic bond leading to depolymerization

\section{$\underline{\text { Abstract }}$}

We report the complete conversion of inulin in gas/liquid media by a dielectric barrier discharge plasma at atmospheric pressure. Depending on the plasma treatment time (from 1 to $30 \mathrm{~min}$ ) and the chemical nature of the gases (air, oxygen, nitrogen), it was possible to depolymerize inulin into fructo-oligosaccharides with a degree of polymerization inferior to 5 or to achieve a total conversion of inulin into its two monomeric constituents, fructose and glucose in 20 min, without any degradation products. Combined results from liquid chromatography (HPLC), solid state Nuclear Magnetic Resonance (ssNMR) and mass spectroscopy revealed that the breakage of the $\beta$ 1-4-bridged oxygen occurs by an acidic attack, following the oxidation of the 
polymer. Infrared spectroscopy revealed the oxidation and breakage of the polymer and also adsorption of nitrate species.

\section{$\underline{\text { Introduction }}$}

Since the industrial revolution, chemistry has developed processes, catalysts and technologies for the conversion of fossil carbon, aiming to create complex and diverse molecules. However, increasing environmental awareness is prompting scientists and manufacturers to develop strategies for environmental sustainability by using processes and materials with low cost, low energy consumption and low toxicity. For several years now, a new approach has been focusing on the use of new raw material from the biomass or waste (Ong et al., 2019; Sheldon, 2018). This change of strategy was revolutionary in the world of chemistry and it has dramatically changed the way a process is designed (Jérôme, Chatel \& De Oliveira Vigier, 2016; Farmer \& Mascal, 2015; Sylla-Iyarreta Veitía \& Ferroud, 2015; Horváth \& Anastas, 2007; Baig \& Varma, 2012; Benoit et al., 2012). For this reason, the use of advanced technologies, such as nonthermal plasma, ultrasounds or ball-milling have been extensively investigated (Farmer \& Mascal, 2015). Current and future society needs scientists and manufacturers to focus on new strategies and develop low cost processes for sustainable materials, easy to produce and widely available (Jérôme, 2016)

The recent extensive use of non-thermal plasma is the result of a range of reaction parameters that cannot be accessible otherwise, or to a lesser extent. No other media can provide gas temperatures or energy densities as high as those of plasmas; no other media can excite atomic and molecular species to radiate as efficiently; no other media can be arranged to provide comparable transient and non-equilibrium conditions (National Research Council, 1991). This technology is safe, versatile, easy to carry out and allows the generation of highly reactive chemical species with low energy consumption, low toxicity and the possibility of continuous processing (Kan, Lam, Chan, \& Ng, 2014). 
The development of atmospheric pressure plasma technologies has dramatically increased in recent years due to their potential impact in a very wide range of applications that include surface treatments (cleaning, etching), surface activation, surface coating (air plasma spray, plasma enhanced chemical vapor deposition) (Tendero, Tixier, Tristant, Desmaison \& Leprince, 2006), but also food (decontamination, toxin degradation, packaging), medicine (sterilization, wound healing, skin treatments) and water (pesticide and dyes degradation, decontamination) (Pankaj \& Keener, 2017). The technological progress has encouraged the interest and advancement in the understanding of plasmas. The possibility of performing reactions at atmospheric pressure is becoming increasingly attractive and the fundamental and essential role of technological plasmas is set to expand significantly in the coming years 0(Mariotti, Patel, Švrček \& Maguire, 2012).

In this context, production of fructose from fructans such as inulin using plasma, is an alternative to the current approaches, such as acid or enzymatic hydrolysis (Raccuia et al., 2016). Inulin is constituted of fructose units connected by $\beta$ (1-2) linkages with a glucose at its extremity linked in $\alpha$ (1-2) form. In the inulin chain, the fructose is blocked in the furanose form and glucose is in glucopyranose form. Inulin, its derivatives and its two constitutive monomers have received considerable interest as food ingredients (Blecker, Fougnies, Van Herck, Chevalier \& Paquot, 2002). Inulin has also been chemically modified in several ways (neutral, anionic, and cationic modification as well as cross-linking and slow release applications) to obtain highly biodegradable compounds at the industrial scale (Stevens, Meriggi \& Booten, 2001).

The effect of non-thermal atmospheric plasma on inulin was already investigated on solid material in gas phase but the reaction mechanism was not completely elucidated [Nastase, Tatibouët \& Fourré, 2018; Benoit \& al., 2012). The authors reported the depolymerization of inulin with a yield of $16 \mathrm{wt} \%$ of fructose (other products being fructo-oligosaccharides (FOS) 
with a degree of polymerization (DP) lower than 6) via the surrounding water initially contained in polysaccharides that promotes the cleavage of the glycosidic bonds (Benoit \&al.). In a recent study (Nastase, Tatibouët \& Fourré, 2018), it was suggested that reactive oxidizing species generated by oxygen (ROS) and nitrogen (RNS) played a key role in the depolymerization process, via $\mathrm{OH}$ radicals or nitric acid attack.

Nowadays, within the field of plasma science and technology, the attention is increasing over the plasma-liquid interactions, and particularly on the physical and chemical mechanisms leading to complex reaction at the plasma-liquid interface (Bruggeman et al, 2016). It is well admitted in the literature that discharges generated at the gas-liquid interface provide gaseous reactive species that can dissolve in the liquid media, inducing the formation of species presenting high reactivity, such as $\mathrm{H}_{2} \mathrm{O}_{2}, \mathrm{NO}_{2}{ }^{-} / \mathrm{NO}_{3}{ }^{-}, \mathrm{OH}^{*}, \mathrm{HOO} / \mathrm{O}_{2}{ }^{-}$to name a few. The fundamental properties of liquid-phase plasma (like generation, state or reactive species) have not been fully described, but the presence of liquid in the system leads to higher reaction rate since the molecular density in the liquid phase is much higher than in the gas phase (Takai, 2008). However, plasmas in liquids are more difficult to control and stabilize: the liquid is often an electrode, therefore evaporation and chemical modification occurs, which adds significant complexity compared to the gas phase plasmas (Bruggeman \& Leys, 2009).

In this respect, a reactor with a double dielectric (DD) barrier, combining a liquid and gas phase DD-LG plasma has been developed. The configuration of the reactor used along this study allows the initiation of various types of reactions: plasma active species formed in the gas and at the gas-liquid interface are further transferred into the liquid giving rise to more chemical reactions. The novelty of this configuration resides in the isolation of the liquid phase between the 2 electrodes, which can avoid problems like electrode evaporation (when using liquid electrode) or contamination from the metal electrode in contact with the liquid. This plasma configuration has been used to follow depolymerization of inulin into FOS, fructose and glucose 
investigated in controlled conditions in power, time, chemical nature of the gas phase and sample concentration.

Throughout this study, commercial inulin (from chicory, Sigma Aldrich) was used as a substrate. Inulin was solubilized in ultra-pure water under stirring at room temperature, to obtain a concentration of 8 g.L. $\mathrm{L}^{-1}$ without further treatment.

\subsection{Gas-liquid plasma device}

Plasma treatment was carried out in a dielectric barrier discharge reactor consisting in a double wall glass cylinder separated in two parts by a fritted glass (figure 1). This reactor can be classified as multiphase discharge (Bruggeman et al., 2016) except that both electrodes are isolated from the liquid phase by two glass walls. The first electrode (inox tube) stands in the center of the cylinder and was protected from the liquid by a first dielectric wall. The second electrode (copper adhesive tape, from Advance tape) was wrapped around the second dielectric wall, on the outside wall of the cylinder. The gap between both dielectrics was $3 \mathrm{~mm}$. A high voltage supply (A2E Technologies Enertronic), was connected to the electrodes and providing bipolar voltage pulses, allows the variation of the voltage from 0 to $40 \mathrm{kV}$. The gas (flow of 30 $\mathrm{mL} \cdot \mathrm{min}^{-1}$ ) was introduced in the reactor from the bottom entry and was flown through a fritted glass which not only created bubbles, but also prevented the liquid from draining. The volume of the solution to be treated was set at $5 \mathrm{~mL}$, allowing the generation of plasma in the gas phase, right above the surface of the liquid and, in a lesser extent, in the gas bubbles through the liquid. The solution was injected in the system kept at atmospheric pressure, room temperature and with the gas flow set at $30 \mathrm{~mL} \mathrm{~min}^{-1}$. In order to determine the optimal parameters for inulin conversion, the electrical parameters (voltage, $16-21 \mathrm{kV})$ and the treatment time (1-40 min) 


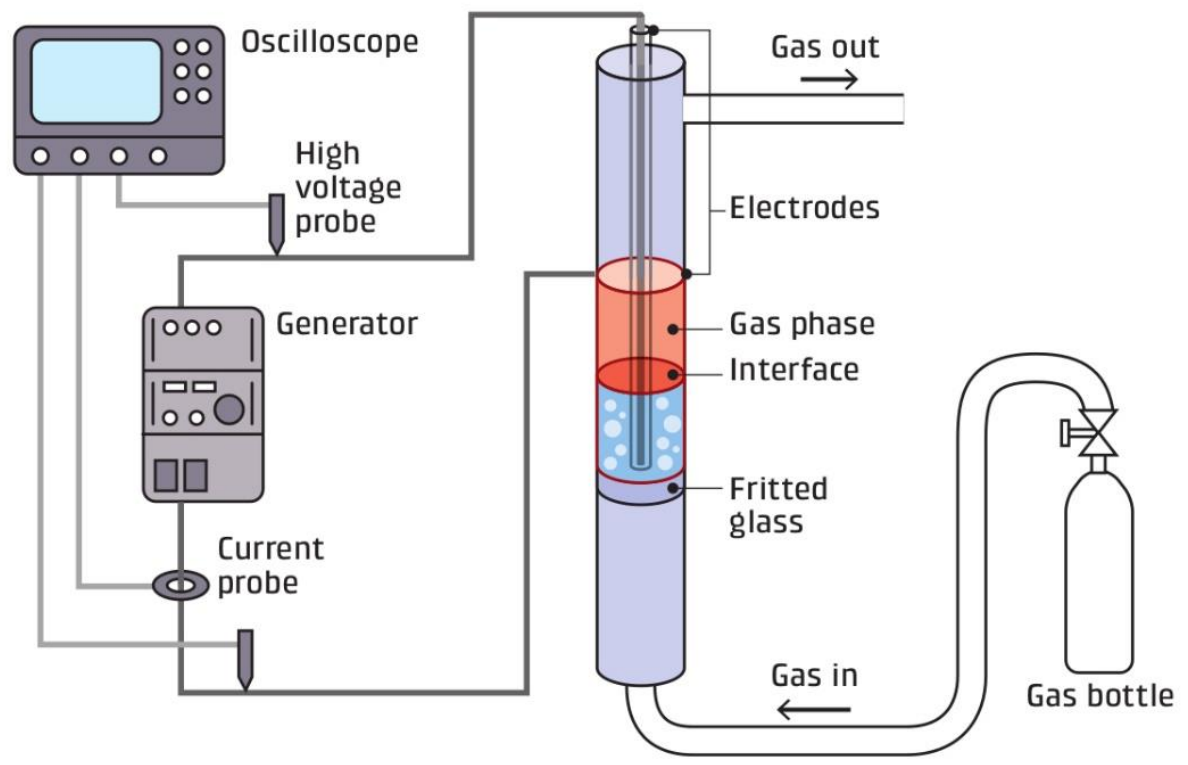

Figure 1: Drawing of the experimental setup

Hydrogen peroxide produced during the plasma treatment was calculated from colorimetric titration with potassium permanganate, in acidic conditions. $10 \mathrm{~mL}$ of plasma treated sample was placed in a beaker with $20 \mathrm{~mL}$ distilled water and $10 \mathrm{~mL}$ of $\mathrm{H}_{2} \mathrm{SO}_{4}$ solution $(3 \mathrm{M})$. The solution was magnetically stirred and a solution of $\mathrm{KMnO}_{4}(0.025 \mathrm{M})$ was added dropwise through a graduated burette. The concentration was calculated from the equivalent point

141 volume.

143 High Pressure Liquid Chromatography was used to determine the presence of oligosaccharides 144 after plasma processing. Samples were analyzed on a Shodex Sugar KS-802 column 145 (maintained at $40^{\circ} \mathrm{C}$ ) that allows the separation of oligosaccharides by steric exclusion and 
ligand exchange. The stationary phase consists of polystyrene-divinylbenzene coated with a cation exchange resin and the mobile phase consists of ultra-pure water at a flow rate of 1 $\operatorname{mL} \cdot \min ^{-1}$.

Molecules were eluted depending on their hydrodynamic volume. The concentrations of fructose and glucose were defined for each compound by a calibration curve established with different concentrations (supplementary information), giving the concentration in $\mathrm{g} . \mathrm{L}^{-1}$ of the analyzed compound as a function of the area of the chromatographic peaks.

\section{Solid state Nuclear Magnetic Resonance}

Solid state ${ }^{13} \mathrm{C}$ NMR experiments were carried out using a Bruker Avance III $400 \mathrm{MHz}$ spectrometer operating at a ${ }^{13} \mathrm{C}$ frequency of $100.62 \mathrm{MHz}$ and equipped with a CP/MAS $4 \mathrm{~mm}$ ${ }^{1} \mathrm{H} /{ }^{13} \mathrm{C}$ probe. Prior to the analysis, the samples were neutralized with a solution of $\mathrm{NaOH}(0.1$ M) and lyophilized. The $\mathrm{pH}$ was measured with a pHmeter (Eutech instrument $\mathrm{pH} 510$ ). The solid samples were packed in a $4 \mathrm{~mm}$ NMR rotor without any other preparation. The sample were spun at a rate of $9 \mathrm{kHz}$ at room temperature. The cross polarization pulse sequence parameters were as follow : $3.95 \mu$ s for proton $90^{\circ}$ pulse, a contact time between 0.8 and 2.0 $\mathrm{ms}$ and $10 \mathrm{~s}$ recycle time. Usually, the accumulation of 5120 scans was used. The carbonyl signal of glycine (176.03 ppm) was used to calibrate the chemical shift of the ${ }^{13} \mathrm{C}$ NMR spectra. The chemical shift, peak half-width and peak area of the different peaks were determined with a least squares fitting method using Peakfit@ software

\section{Mass spectrometry}

The samples analyzed by ssNMR were also analyzed by matrix-assisted laser desorption/ionization (MALDI)-time-of-flight (TOF) MS. For the measurements, an ionic preparation of 2,5-dihydroxybenzoic acid (DHB) and N,N-dimethylaniline (DMA) was used as the MALDI matrix, as described in (Ropartz, 2011). Briefly, the matrix consists of a mixture 
of DHB and DMA (DHB $100 \mathrm{mg} \cdot \mathrm{ml}^{-1}$, in $\mathrm{H}_{2} \mathrm{O} /$ acetonitrile/ DMA (1:1:0.02)) and was mixed with the samples in a 1:1 ratio $(\mathrm{v} / \mathrm{v})$. The mixture $(1 \mu \mathrm{L})$ was then deposited on a polished steel MALDI target plate. MALDI measurements were then performed on an Autoflex Speed MALDI-TOF/TOF spectrometer (Bruker Daltonics, Bremen, Germany) equipped with a Smartbeam laser $(355 \mathrm{~nm}, 1000 \mathrm{~Hz})$ and controlled using the Flex Control 3.0 software package. The mass spectrometer was operated with positive polarity in reflectron mode. Spectra were acquired in the range of $180-3500 \mathrm{~m} / \mathrm{z}$.

The evolution of the percentage of DP 1 was then monitored using the following formula:

$\%=\frac{I_{D P 1}}{I_{D P 1}+I_{D P 2}+I_{D P 3}+I_{D P 4}} \quad$ equation 1

\section{$F T-I R$}

Fourier transform infrared spectroscopy was performed before and after plasma treatment in order to observe the eventual functionalization and/or stabilization of species on the surface of inulin. Prior to analysis, the sample was lyophilized. The powder sample $(5 \mathrm{mg})$ was mixed with $\mathrm{KBr}(100 \mathrm{mg})$ and pressed in a hydraulic press and then recovered in the form of a pellet. The analysis was carried out in a Nicolet IS50 spectrometer in transmission mode and the resulting spectra were an average of 200 scans at a resolution of $16 \mathrm{~cm}^{-1}$. All spectra were baseline corrected and normalized to be compared to each other.

\section{Results and discussion}

\subsection{Reactor optimization}

In order to identify the reactivity sites (in gas bubbles, in the upper gas phase or at liquid-gas interface) and to evaluate the discharge propagation, the effect of the volume of liquid submitted to plasma was studied, introducing $5 \mathrm{~mL}, 10 \mathrm{~mL}$ and $15 \mathrm{~mL}$ of an aqueous solution of inulin at 8 g.L $\mathrm{L}^{-1}$ (figure 2). The experiments were carried out at constant voltage $(19 \mathrm{kV})$, frequency (2 $\mathrm{kHz}$ ) and time (20 min). The efficiency of the plasma discharge was evaluated by its impact on 
inulin depolymerization via the following of fructose yields, $\mathrm{pH}$, and $\mathrm{NO}_{2}{ }^{-} / \mathrm{NO}_{3}{ }^{-}$and $\mathrm{H}_{2} \mathrm{O}_{2}$ concentrations.

When $15 \mathrm{~mL}$ were introduced, the inulin solution filled the reactor with $5 \mathrm{~mL}$ of the volume standing above the external electrode limit. No depolymerization occurred in this configuration. Additionally, no $\mathrm{pH}$ change was observed and no other species were detected (Table 1). It appeared that the observed discharge was occurring in the tube holding the central electrode, as a very small air gap was present between the electrode and the inner wall of the dielectric barrier (visible on figure 1). When the inner tube was sealed with glue, no plasma discharge was observed, neither depolymerization.

When $10 \mathrm{~mL}$ of solution were inserted in the reactor, it allowed the development of the plasma at the gas-liquid interface but without (or very little) plasma in the gas phase. A concentration of only 0.14 g. $\mathrm{L}^{-1}$ of fructose was detected and, in the same time, $\mathrm{pH}$ dropped from 6.5 (untreated solution) to 5.0. Using semi quantitative test strips (Quantofix), a small fraction of $\mathrm{NO}_{\mathrm{x}}{ }^{-}$species were measured indicating the dissolution of nitrous oxides into nitrites $\left(1 \mathrm{mg} . \mathrm{mL}^{-}\right.$ $\left.{ }^{1}\right)$ and nitrates $\left(\leq 10 \mathrm{mg} \cdot \mathrm{mL}^{-1}\right)$.

Finally, $5 \mathrm{~mL}$ of solution introduced resulted in a system with two phases of plasma, at interface and in the gas phase. In this case, inulin was totally depolymerized into fructose $\left(7 \mathrm{~g} . \mathrm{L}^{-1}\right)$, glucose $\left(0.25\right.$ g.L $\left.\mathrm{L}^{-1}\right)$ and a compound of DP 2 . It clearly showed that the most effective reaction occurred when the gas-liquid interface and even more importantly, the plasma in gas phase are present. From these results, the configuration using $5 \mathrm{~mL}$ of solution was kept throughout the study.

The fact that the depolymerization was enhanced in presence of a gas phase highlighted the fact that the long lived plasma species from the gas phase may be responsible of the reactivity. Their dissolution in the liquid media would lead to active species capable to dissociate the polymer. 
In order to verify this hypothesis the reactor was turned upside down, allowing only the contact of the plasma long lived species with the liquid. It resulted in no modification of the inulin chain. The $\mathrm{pH}$ of the solution decreased to 3.4 , indicating the dissolution of acidic species from the gas phase in the liquid, but no depolymerization occurred. It has been established in the literature (Bruggeman et al;, 2016; Takai, 2008) that the active species generated in the gas phase are transferred from the gas to the liquid phase, creating more reactive species such as $\mathrm{H}_{2} \mathrm{O}_{2}$, peroxonitrites $\left(\mathrm{ONOO}^{-}\right)$and nitric acid $\left(\mathrm{HNO}_{3}\right)$. Among the species commonly produced in the liquid phase, $\mathrm{H}_{2} \mathrm{O}_{2}, \mathrm{NO}_{2}{ }^{-}$and $\mathrm{NO}_{3}{ }^{-}$were detected in the samples after plasma treatment (Table 1). In the case of air treatment, $\mathrm{NO}_{3}{ }^{-}$was detected up to $500 \mathrm{mg} \cdot \mathrm{mL}^{-1}$.

Table 1: $\mathrm{pH}, \mathrm{NO}_{2}{ }^{-} / \mathrm{NO}_{3}{ }^{-}$and $\mathrm{H}_{2} \mathrm{O}_{2}$ concentrations measured after 20 min of air plasma treatment for different liquid volumes. Parameters: $\mathrm{P}=28 \mathrm{~W}$, gas flow $=30 \mathrm{~mL} \cdot \mathrm{min}^{-1}, \mathrm{f}=2 \mathrm{kHz}$; [inulin] $=8 \mathrm{~g} \cdot \mathrm{L}^{-1}$

\begin{tabular}{|l|c|c|c|c|}
\hline Volume & $15 \mathrm{ml}$ & $10 \mathrm{ml}$ & $5 \mathrm{ml}$ & $\begin{array}{c}\text { Upside down (5 } \\
\mathrm{mL})\end{array}$ \\
\hline $\mathrm{pH}$ & 6.5 & 5 & 1.5 & 3.4 \\
\hline $\mathrm{H}_{2} \mathrm{O}_{2} \mathrm{mg} \cdot \mathrm{mL}^{-1}$ & 0 & 10 & 11.2 & 1.5 \\
\hline $\mathrm{NO}_{2}{ }^{-} \mathrm{mg} \cdot \mathrm{mL}^{-1}$ & 0 & 1 & 15 & 0 \\
\hline $\mathrm{NO}_{3}^{-} \mathrm{mg} \cdot \mathrm{mL}^{-1}$ & 0 & 15 & 500 & 350 \\
\hline
\end{tabular}

In order to further identify and evaluate the reactivity of plasma chemical active species in such a system, the depolymerization reaction of inulin was performed using different gases. The results are summarized in table 2. The highest concentration of $\mathrm{H}_{2} \mathrm{O}_{2}$ was measured under oxygen and $\mathrm{O}_{2} / \mathrm{He}$ plasma. Under nitrogen and air plasma the $\mathrm{H}_{2} \mathrm{O}_{2}$ concentrations were lower, due to the presence of $\mathrm{NO}_{2}^{-}$, which in acidic conditions can lead to the $\mathrm{H}_{2} \mathrm{O}_{2}$ degradation 

lowest concentration was measured under pure helium plasma.

Table 2: fructose concentration, $\mathrm{pH}$ and oxidized species concentrations measured after $20 \mathrm{~min}$ of plasma treatment for different gas phases. Parameters: gas flow $=30 \mathrm{~mL} \cdot \mathrm{min}-1, \mathrm{f}=2 \mathrm{kHz}$; [inulin $]=8 \mathrm{~g} \cdot \mathrm{L}^{-1}$

\begin{tabular}{|c|c|c|c|c|c|}
\hline Gas nature & $100 \% \mathrm{O}_{2}$ & $\begin{array}{c}100 \% \\
\mathrm{He}\end{array}$ & $\begin{array}{c}50 \% \mathrm{He} / \\
50 \% \mathrm{O}_{2}\end{array}$ & $100 \% \mathrm{~N}_{2}$ & Synthetic air \\
\hline Power (W) & 12 & 12 & 28 & 14 & 28 \\
\hline $\begin{array}{c}\text { Fructose conc. } \\
\left(\mathrm{g} . \mathrm{L}^{-1}\right)\end{array}$ & 0.3 & 0.02 & 0.3 & 0.9 & 7 \\
\hline $\mathrm{pH}$ & $3-4$ & $3-4$ & $3-4$ & 1.5 & 1.5 \\
\hline $\mathrm{H}_{2} \mathrm{O}_{2}\left(\mathrm{mmol} . \mathrm{L}^{-1}\right)$ & 15.5 & 3.6 & 13.7 & 10 & 11.2 \\
\hline $\mathrm{NO}_{3}{ }^{-}\left(\mathrm{mg} . \mathrm{L}^{-1}\right)$ & none & none & none & $250 \geq \mathrm{x} \geq 500$ & $\geq 500$ \\
\hline $\mathrm{NO}_{2}{ }^{-}\left(\mathrm{mg} . \mathrm{L}^{-1}\right)$ & none & none & none & $5<\mathrm{x}<10$ & 15 \\
\hline
\end{tabular}

The fructose concentration measured after plasma treatment under helium was the lowest $(0.02$ g. $\left.\mathrm{L}^{-1}\right)$. The actives species generated under helium plasma such as $\mathrm{He}^{*}, \mathrm{He}_{2}{ }^{*}, \mathrm{He}^{+}$and $\mathrm{He}_{2}{ }^{+}$, but also dissolved oxygenated species generated from electron and helium impact on water molecules, are not participating in the reaction in the first $30 \mathrm{~min}$. Oxygen gas appeared also quite inert since the addition of oxygen to helium gas and higher injected power in the reactor did not affect the fructose yield as compared with pure oxygen $\left(0.3 \mathrm{~g} \cdot \mathrm{L}^{-1}\right)$. When pure nitrogen was flown through the system, a slight increase of fructose concentration was observed but to a lesser extent compared to air treatment where inulin was totally converted. It is worth mentioning that an air plasma treatment at $12 \mathrm{~W}$ resulted in no conversion.

The HPLC results of the plasma treatment under synthetic air showed the progressive depolymerization of inulin into smaller fractions and its two constituents, glucose and fructose. Air plasma is the most effective treatment for the inulin depolymerization. A treatment time of approximatively $20 \mathrm{~min}$ allowed the total conversion of inulin (figure 2). The concentration of fructose was 7 g.L $\mathrm{L}^{-1}$ reaching a plateau at 20 and $30 \mathrm{~min}$. Interestingly, the glucose concentration 
(figure $2 \mathrm{~b}$ ) increased until $30 \mathrm{~min}$ of treatment $\left(0.4\right.$ g.L. $\left.\mathrm{L}^{-1}\right)$. It appears that the reactive species derived from the reactions between nitrogen and oxygen in the air plasma are responsible for the depolymerization. Nitrous oxides solvation in water would lead to nitric and nitrous acids, providing $\mathrm{H}^{+}$ions and consequently acid hydrolysis of the polymer.
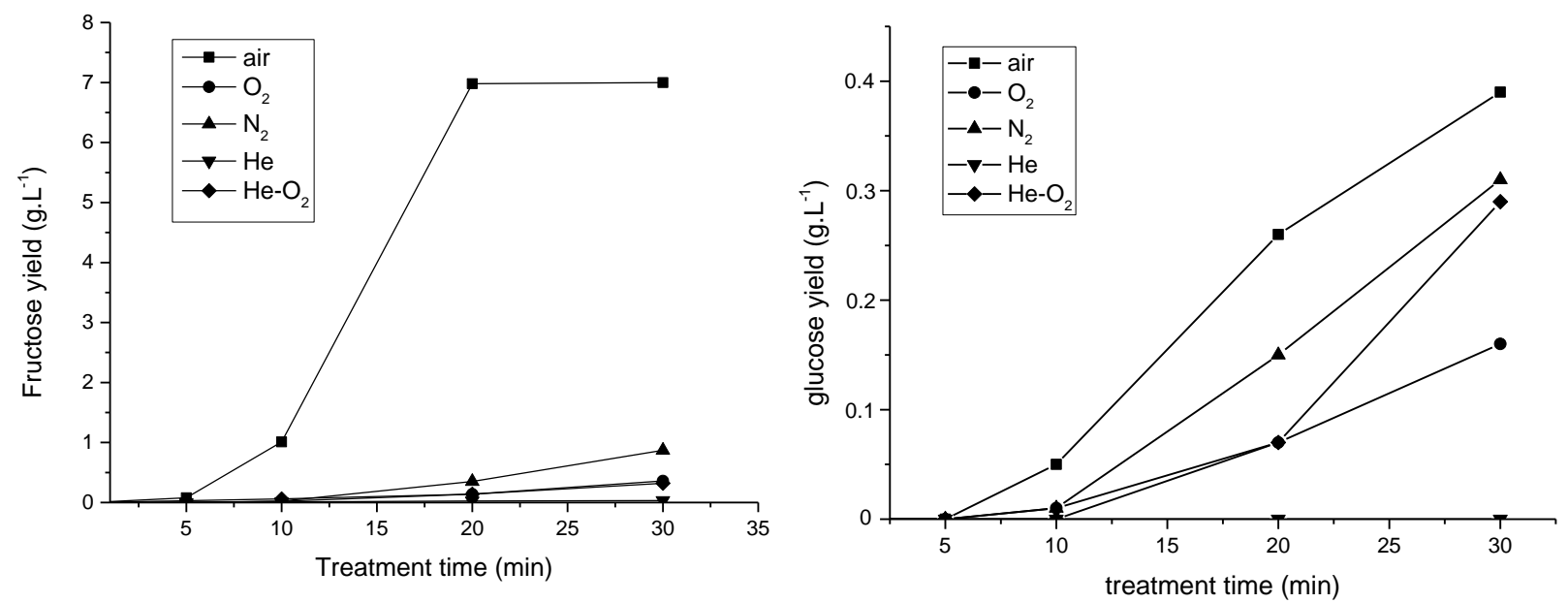

Figure 2: plot of a) fructose and b) glucose yields as a function of treatment time. Conditions: $2 \mathrm{kHz}, 30$ $\mathrm{mL} \cdot \mathrm{min}^{-1} ; \mathrm{P}=28 \mathrm{~W}$ and $\mathrm{P}(\mathrm{He})=12 \mathrm{~W} ;$ [inulin $]=8 \mathrm{~g} \cdot \mathrm{L}^{-1}$

A series of tests with nitric acid were performed in order to confirm this hypothesis. When $5 \mathrm{ml}$ of inulin solution were mixed with nitric acid $\left(1 \mathrm{~mol} \cdot \mathrm{L}^{-1}\right)$ till a $\mathrm{pH}=1.5$, followed by $80^{\circ} \mathrm{C}$ heating from 20 to $100 \mathrm{~min}$, a total conversion into fructose $\left(8 \mathrm{mg} \cdot \mathrm{ml}^{-1}\right)$ was achieved. The same result was obtained when inulin powder was added to plasma treated water (in air; $\mathrm{P}=28 \mathrm{~W}$ ) and heated up at $80^{\circ} \mathrm{C}$. The $\mathrm{pH}$ of the water treated with air plasma equaled 1.5. These experiments confirmed the participation of $\mathrm{H}^{+}$in the depolymerization process.

\subsection{Elucidating the depolymerization process}

${ }^{13} \mathrm{C}$ CP/MAS NMR spectroscopy was used for anomer analyses of reducing terminal units of the treated chains in order to follow depolymerization under air plasma treatment, which proved to be the most efficient treatment. A freeze dried reference (no plasma) was prepared and compared to samples treated in air up to $20 \mathrm{~min}$. The structure of inulin (a), along with the $\beta$ - 
D-fructopyranose form (b) detected in some samples is represented in figure 6 . When 286 glucopyranose is present at the reducing end, the fructose molecules are in the furanose form.

287 Without glucose at the end, the fructose molecules are in the pyranose form (Levy \& Fügedi, 288 2005). The labelling on the NMR spectra are also referenced in figure 3.

289

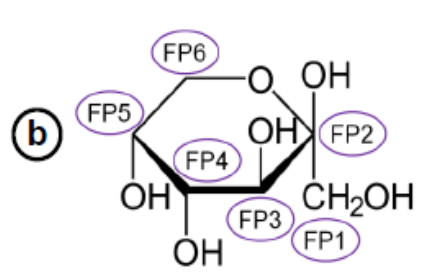

$$
\text { HO }
$$
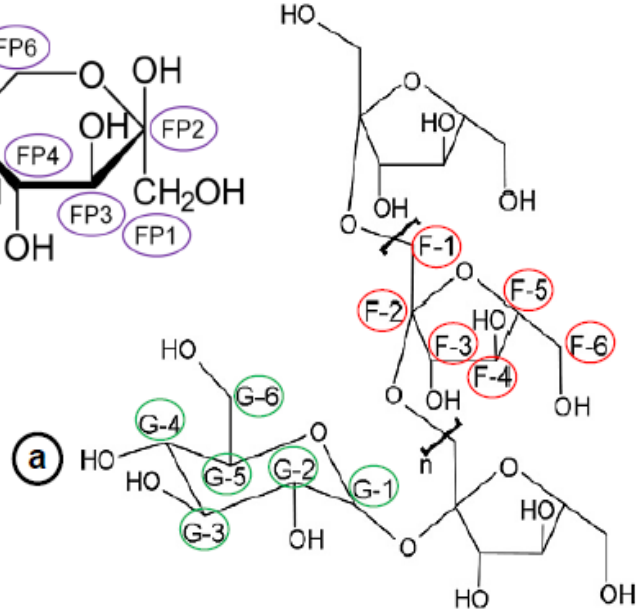

290

291

292

293

Figure 3: Structure of a) inulin and b) $\beta$-D-fructopyranose

After spectral deconvolution, the average degrees of polymerization have been calculated using the next formula:

For untreated inulin, the lyophilized untreated inulin and inulin treated by plasma for 3 min:

DP average $=\frac{\left[\frac{\text { Larea from } 83 \text { to } 57 \mathrm{ppm}}{5}\right]-\text { area at } 93 \mathrm{ppm}}{\text { area at } 93 \mathrm{ppm}}$

Equation 2

The numerator corresponds to the signal of fructose monomers subtracted from glucose contribution (figure 4). The denominator corresponds to the signal of anomeric carbons of ending glucose.

Inulin treated by plasma from 7 to $40 \mathrm{~min}$ :

$D P$ average $=\frac{\left[\left(\sum \text { area from } 83 \text { to } 57 \mathrm{ppm}\right) / 5\right]-(\text { area at } 93 \mathrm{ppm}+\text { area at } 98 \mathrm{ppm})}{(\text { area at } 93 \mathrm{ppm}+\text { area at } 98 \mathrm{ppm})} \quad$ Equation 3 
The peak at $93 \mathrm{ppm}$ corresponds to the glucose reducing end in the $\alpha$ conformation and the

302

303 peak at $98 \mathrm{ppm}$ in the $\beta$ conformation or $\mathrm{C}_{2}$ from fructopyranose (Colombo, Aupic, Lewis \& Mario Pinto, 2015).

The NMR analysis of the freeze dried reference (figure 4) highlighted the presence of fructopyranose form of inulin and showed that the freeze-drying step was also affecting the supramolecular organization of inulin. The widening of the bands at $103 \mathrm{ppm}$ and in both regions 86-70 ppm and 68-54 ppm reflected a less ordered structure after lyophilization, most probably arising from a loss of the crystallinity. In addition, the chemical shift of $\mathrm{C}_{1}(\mathrm{~F} 1)$ of fructose, between 80 and 74 ppm, was modified suggesting a significant change of the magnetic environment.

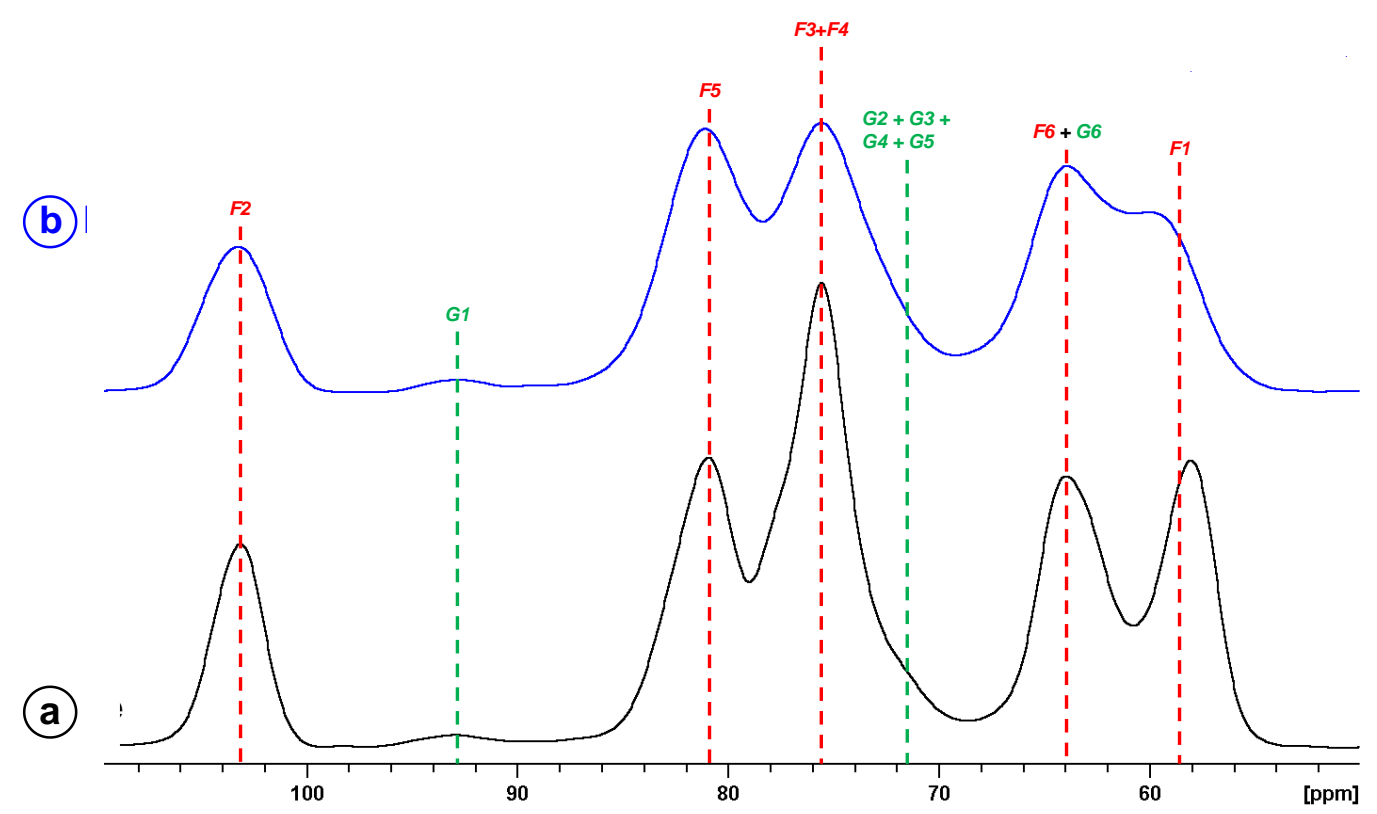

Figure 4: ${ }^{13} \mathrm{C}$ CP/MAS inulin spectra, (a) initial state, (b) after solubilization and lyophilization. (Annotations are referring to figure 3). 

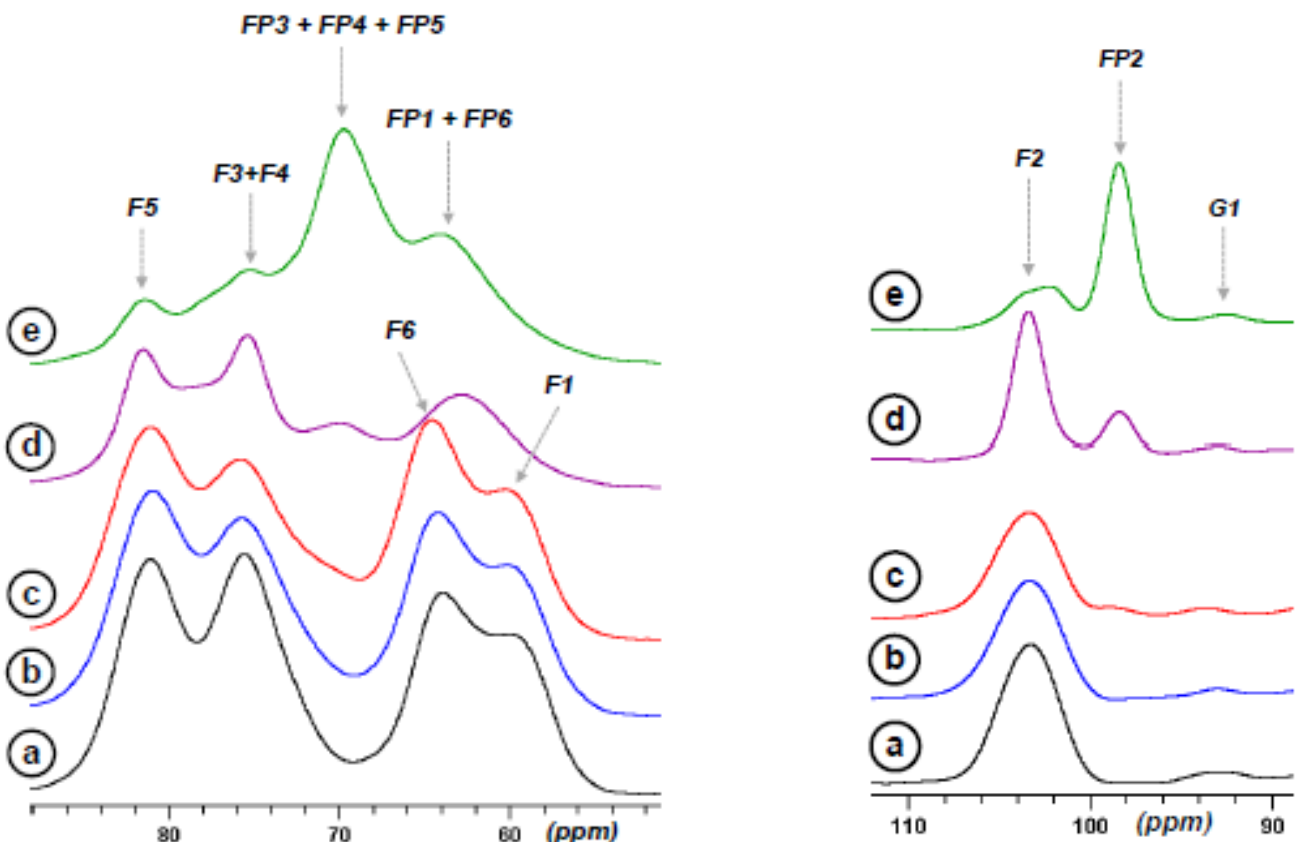

Figure 5: ${ }^{13} \mathrm{C} \mathrm{CP} / \mathrm{MAS}$ spectra zones of non-anomeric carbons (left panel) and anomeric carbon (right panel) of (a) lyophilized inulin (reference) and after plasma treatment of (b) $3 \mathrm{~min}$, (c) $7 \mathrm{~min}$, (d) $13 \mathrm{~min}$, (e) $20 \mathrm{~min}$. (Annotations are referring to figure 6)

Figure 5 shows the ${ }^{13} \mathrm{C} \mathrm{CP} / \mathrm{MAS}$ spectra of inulin before and after up to 20 min of plasma treatment. As the time of plasma treatment increased, peaks in the $110-90 \mathrm{ppm}$ and $90-55$ ppm regions evolved differently. The anomeric and non-anomeric carbon peaks of furanose ring, labelled F1 to F6, are decreasing as the treatment time increases. At 7 min of treatment, an anomeric carbon (FP2) presenting a chemical shift at $98.4 \mathrm{ppm}$ is emerging, identified as $\mathrm{C}_{2}$ carbons of free fructose in the $\beta$-D-fructopyranose form (Colombo, Aupic, Lewis \& Mario Pinto, 2015; Shiomi \& Onodera, 1990). The proportion of this signal increases with treatment time. The presence of free $\beta$-D-fructopyranose is confirmed by peaks in the non-anomeric carbon region at $70 \mathrm{ppm}$ and $84 \mathrm{ppm}$, which increases as a function of treatment time. It is worth mentioning that the pyranose form of fructose was predominant during the solubilization step of monomeric fructose. This result indicates that the conversion from the furanose to 
pyranose form is most likely to occur during the neutralization step and is not due to the plasma treatment.

333 From equations (2) and (3), average values of the degrees of polymerization were calculated 334 (table 3). It shows that after 3 min, a clear depolymerization occurs as already shown by the HPLC. A progressive decrease of the DP was observed as a function of the plasma treatment time up to monomers, without further degradation.

Table 3: Calculated average degree of polymerization (DP) of air plasma treated inulin: $\mathrm{P}=28 \mathrm{~W} ; \mathrm{f}=2$ $338 \mathrm{kHz}$; flow rate: $30 \mathrm{~mL} \cdot \mathrm{min}^{-1}$

\begin{tabular}{|l|l|}
\hline & DP \\
\hline Commercial inulin & 30 \\
\hline Lyophilized inulin & 29 \\
\hline $3 \mathrm{~min}$ & 27 \\
\hline $7 \mathrm{~min}$ & 13 \\
\hline $13 \mathrm{~min}$ & 3 \\
\hline $20 \mathrm{~min}$ & 1 \\
\hline
\end{tabular}

340 To investigate the molecular polydispersity of the released products and more specifically the

341 proportion of DP 1 throughout the treatment of inulin by the plasma, MALDI-TOF MS analyses

342 were performed (figure 6). The evolution of the proportion of DP 1 compared to DP 2, 3 and 4

343 was monitored by mass spectrometry, using the equation 1 . These experiments showed that 344 above $20 \mathrm{~min}$, it remains almost only DP 1 species (glucose and/or fructose). This result is according to NMR measurements. 


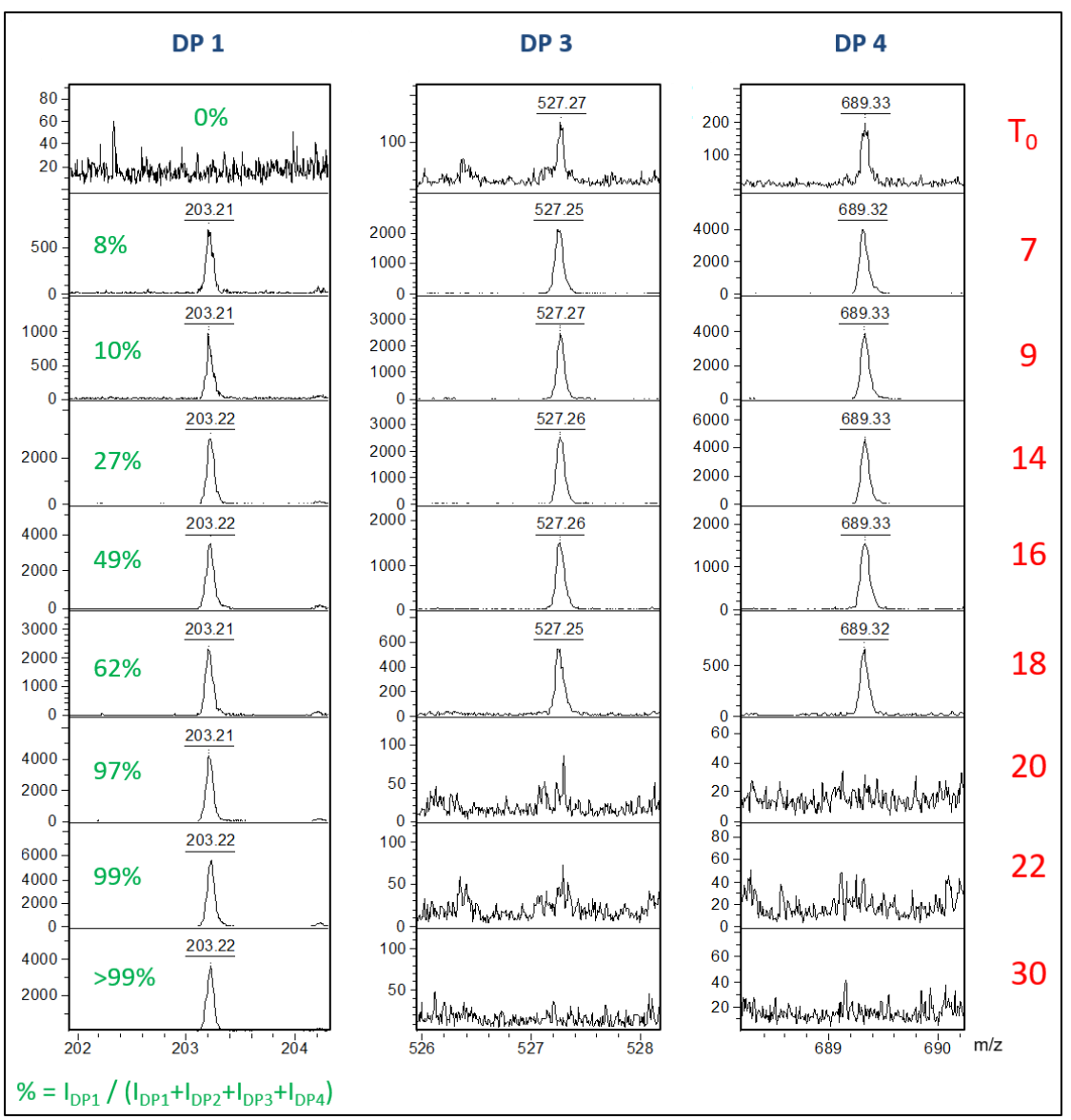

Figure 6: Evolution of the signal of DP 1, 3 and 4 by mass spectrometry as a function of plasma treatment time. Oligosaccharides are detected as sodium adducts. The percentage of DP 1 was determined using equation 1 . The DP2 is not represented for esthetic reason, due to the presence of numerous matrix peaks in the same region.

While fructose and glucose both crystallize as cyclic forms, in solution the free sugars show an equilibrium with an acyclic form in small amount, the formation of which creates a carbonyl group (Levy \& Fügedi, 2005). This carbonyl group can react with hydroxyl groups restructuring the hemiacetal cyclic form. For six carbon carbohydrates, like glucose and fructose, the ring closing reaction can occur with more than one hydroxyl group, leading to isomerization and multiple cyclic forms. Inulin is relatively chemically inert, although cleavage of the polymer chain at any of the glycosidic bonds will produce a reactive reducing end, prone to further reaction (Stevens, Meriggi \& Booten, 2001; Wack \& Blaschek, 2006). 
Infrared analysis was used routinely for the assessment of chemical structure of treated inulin. The full IR description of raw inulin has been described elsewhere (Grube, Bekers, Upite \& Kaminska, 2002; Ibrahim, Alaam, El-Haes, Jalbout \& de Leon, 2006; Wack \& Blaschek, 2006), and can be used as reference. In the first region, between $4000-2000 \mathrm{~cm}^{-1}$, the large broad band at $3300 \mathrm{~cm}^{-1}$, corresponding to the stretching of $\mathrm{OH}$ groups, did not change during the plasma treatment (Figure 7). A sharp band of middle intensity was noticeable at $2930 \mathrm{~cm}^{-1}$, assigned to the valence vibration of $\mathrm{C}-\mathrm{H}$ asymmetric stretching of $\mathrm{CH}_{2}$ and a shoulder at $2890 \mathrm{~cm}^{-1}$ attributed to $\mathrm{C}-\mathrm{H}$ symmetric stretching of $\mathrm{CH}_{2}$. A deviation of the baseline with treatment time, giving rise to a broad absorption between $2400-3000 \mathrm{~cm}^{-1}$ was attributed to the formation of carboxylic acids, under their dimeric form (Bellamy, 1962).

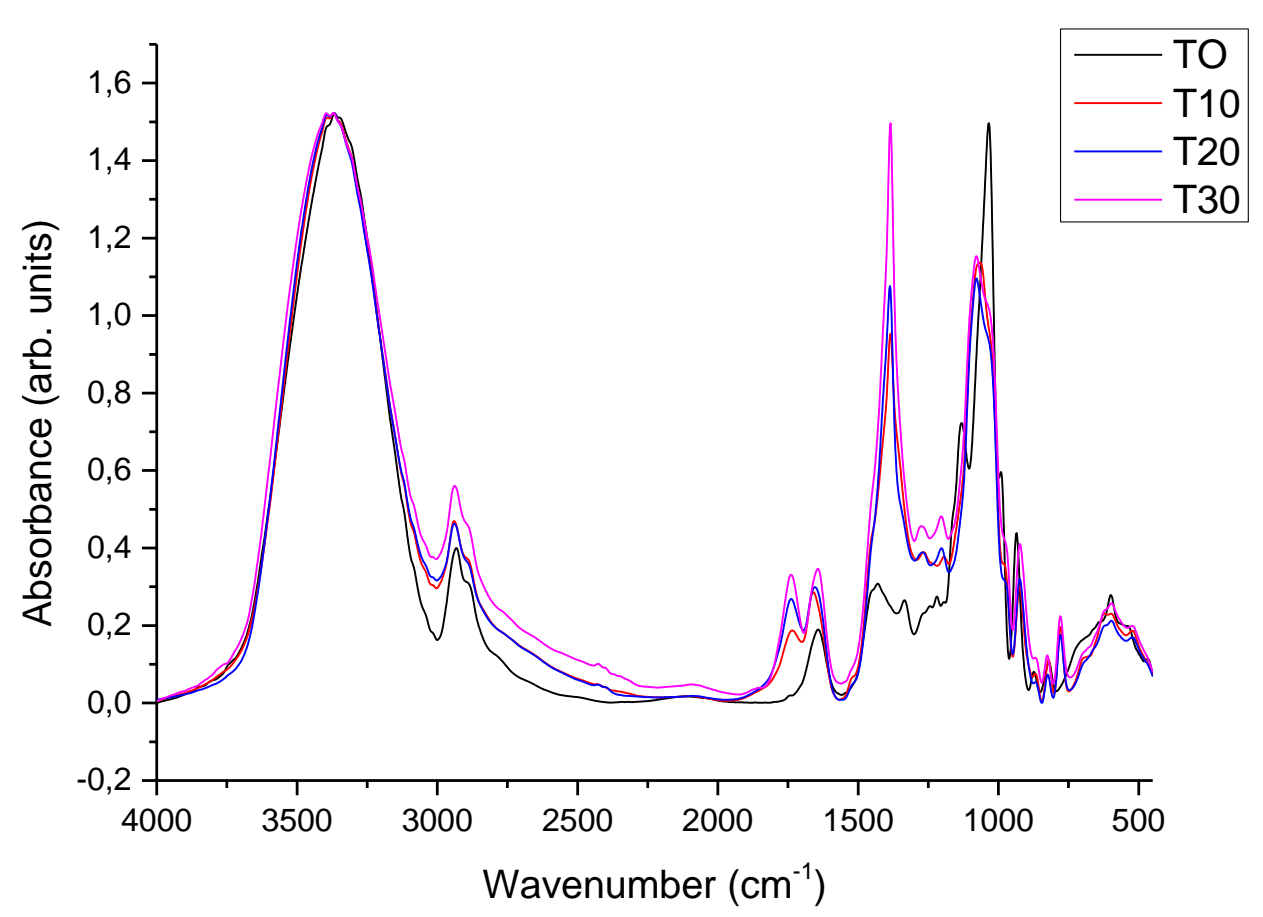
Figure 7: Infrared spectra of inulin as a function of plasma treatment time

374 In the following region, between 2000 and $1100 \mathrm{~cm}^{-1}$, multiple modifications were observed.

375 Plasma treated samples showed the formation of a new band at $1740 \mathrm{~cm}^{-1}$, corresponding to stretching vibrations of $\mathrm{C}=\mathrm{O}$ group. The band at $1640 \mathrm{~cm}^{-1}$, based on the existing literature 
(Higgins, Stewart\& Harrington, 1961), was assigned to adsorbed water. The light shift of the band to $1660 \mathrm{~cm}^{-1}$ was attributed to a change of the electronic environment due to intermediate states generated during the oxidation steps, i.e. $\mathrm{C}=\mathrm{O}$ formation. The bands at 1430 and 1334 $\mathrm{cm}^{-1}$ of the raw inulin are no longer visible after plasma treatment, hidden by the intensive broad band at $1385 \mathrm{~cm}^{-1}$, corresponding to adsorbed nitrate ion (Elmelouky, Mortadi, Chahid \& Elmoznine, 2018). From T10 to T30, the presence of two bands at $1280 \mathrm{~cm}^{-1}$ and at $1205 \mathrm{~cm}^{-1}$ indicate a structure modification from the polymer to the monomer as these bands are related to $\mathrm{OCH}$ and $\mathrm{CCH}$ bending vibrations bands of fructose and glucose. A complete disappearance of the $1130 \mathrm{~cm}^{-1}$ band indicates the loss of C-O-C bridge character.

In the third region $1100-500 \mathrm{~cm}^{-1}$, also known as the fingerprint region, modifications are also visible. Firstly, the band at $1030 \mathrm{~cm}^{-1}$ is reduced and hidden by a band at $1080 \mathrm{~cm}^{-1}$ (D-fructose). All the bands $\left(1035,990,935,872\right.$ and $\left.820 \mathrm{~cm}^{-1}\right)$ related to the fructose/glucose ring structure (C-O-C ring group and ring vibrations) shift slightly towards lower values but are still present, indicating that the integrality of the monomer ring was not affected during the depolymerization. Finally, a new band is formed at $778 \mathrm{~cm}^{-1}$ corresponding to $\mathrm{CCO}$ and $\mathrm{CCH}$ bending of D-fructose and D-glucose. From these data, inulin is depolymerized without degradation of the fructose and glucose rings. First, an oxidation of $\mathrm{C}-\mathrm{OH}$ groups into carboxylic acids takes place. As the plasma treatment time increases, breakage of the C-O-C bridge of the polymer is observed.

It has been established in the literature (Bruggeman \& Leys, 2009; Gorbanev, O'Connell \& Chechik, 2016; Nastase, Tatibouët \& Fourré, 2018; Shainsky, 2012), that various types of plasma-chemical species and reactions are initiated in air plasma in and in contact with liquids. Among the chemical species produced by plasma at the gas-liquid interface, $\mathrm{OH}^{\bullet}$ radical, atomic oxygen, ozone and hydrogen peroxide are the main reactive oxygen species generally accepted (Lukes, Dolezalova, Sisrova \& Clupek, 2014; Sunka, 1999) to play the dominant role 
in the reactivity. As for the nitrogen based species, nitric oxide and its derivatives formed with water (nitrites, nitrates and peroxynitrites) are to be considered. For example, the dissolution of the nitrous oxide gas generated in air plasma (Machala, 2013) leads to the formation of nitric and nitrous acids. The most likely reaction pathway for the depolymerization would be via the hydrolysis of the C-O-C bridge from $\mathrm{H}^{+}$ions of $\mathrm{HNO}_{3}$ arising from the $\mathrm{NO}_{\mathrm{x}}$ dissolution in the liquid. The slight depolymerization observed in nitrogen free plasmas could be attributed to $\mathrm{OH}$ radicals attack of the glycosidic bond. However, this does not explain the decrease of $\mathrm{pH}$ after a plasma treatment without nitrogen. Hydrogen peroxide concentration is too low to induce such pH decrease. Literature reports the formation of acids (Machala, 2013; Shainsky, 2012), arising from superoxide ion, $\mathrm{O}_{2}^{--}$, that participate in the decrease of $\mathrm{pH}$ under nitrogen free plasma discharge and could explain our observation.

\section{$\underline{\text { Conclusions }}$}

The use of renewable polysaccharide feedstocks to produce chemicals is stimulating a revival in carbohydrate chemistry employing green and sustainable processes. In this study, a new reactor has been successfully designed for the treatment of solutions or suspensions in a double dielectric barrier discharge plasma reactor. This specific reactor configuration was used in the depolymerization reaction of inulin. The conversion was strongly dependent on the gas chemical nature and reactor configuration. Pure gases of helium, nitrogen and oxygen had little effect on the depolymerization. However, plasma treatment under air led to a complete depolymerization into fructose, glucose and a DP2 compound. It appears that reactivity is at play at the gas-liquid interface, where electrons and gas species can be solvated and either attack glycosidic bonds of inulin or recombine into more reactive species. Hydrogen peroxide, nitrous and nitric oxides were identified. It appeared that the breakage of the glycosidic bond is achieved by nitric acid hydrolysis under an air plasma discharge, while $\mathrm{OH}$ radicals attack seems to be responsible of the small depolymerization under nitrogen free plasma. There is no 
doubt with these results that the modification of biomass by non-thermal plasma in liquid media represents a new and non-toxic approach that would reconsider the traditional ways.

\section{$\underline{\text { Acknowledgements }}$}

The authors would like to thank the financial supports which are ADEME, Pays de Loire Region and the FR CNRS INCREASE 3707 consortium. The mass spectrometry and NMR analyses were performed using the equipment of the BIBS facility in Nantes (UR1268 BIA, IBiSA, Phenome-Emphasis-FR (grant number ANR-11-INBS-0012)).

\section{$\underline{\text { References }}$}

Baig, RB., \& Varma, RS. (2012) Alternative energy input: mechanochemical, microwave and ultrasound-assisted organic synthesis, Chemical Society Review, 41,1559-84

Bellamy, LJ. (1962) The infra-red spectra of complex molecules, Ed. Methuen \& Co LTD.

Benoit, M., Rodrigues, A., De Oliveira Vigier, K., Fourré, E., Barrault, J., Tatibouët J.-M., \& Jérôme, F. (2012) Combination of ball-milling and non-thermal atmospheric plasma as physical treatments for the saccharification of microcrystalline cellulose, Green Chemistry, 14, 22122215

Benoit, M., Rodrigues, A., Zhang, Q., Fourré, E., De Oliveira Vigier, K., Tatibouët, J-M., \& Jérôme, F. (2011) Depolymerization of cellulose assisted by a non-thermal atmospheric plasma, Angewandte Chemie International Edition, 50, 8964 -8967

Blecker, C., Fougnies, C., Van Herck, J-C., Chevalier J-P., \& Paquot, M. (2002) Kinetic study of the acid hydrolysis of various oligofructose samples, Journal of Agricultural Food Chemistry, 50, 1602-1607

Bruggeman, PJ., Kushner, MJ., Locke, BR., Gardeniers, JGE., Graham, WG., Graves, DB., Hofman-Caris, RCHM., Maric, D., Reid, JP., Ceriani, E., Fernandez Rivas, D., Foster, JE., 
451 Garrick, SC., Gorbanev, Y., Hamaguchi, S., Iza, F., Jablonowski, H., Klimova, E., Kolb, J., 452 Krcma, F., Lukes, P., Machala, Z., Marinov, I., Mariotti, D., Mededovic Thagard, S., Minakata, 453 D., Neyts, EC., Pawlat, J., Lj Petrovic, Z., Pflieger, R., Reuter, S., Schram, DC., Schröter, S., 454 Shiraiwa, M., Tarabová, B., Tsai, PA., Verlet, JRR., von Woedtke, T., Wilson, KR., Yasui, K., 455 \& Zvereva, G. (2016) Plasma-liquid interactions: a review and roadmap, Plasma Sources $456 \quad$ Science and Technologies, 25, 053002

457 Bruggeman, P., \& Leys, C. (2009) Non-thermal plasmas in and in contact with liquids, Journal 458 of Physics D: Applied. Physics, 42, 053001

459 Colombo, C., Aupic, C., Lewis, A.R., \& Mario Pinto, B. (2015) In situ determination of fructose 460 isomer concentrations in wine using ${ }^{13} \mathrm{C}$ quantitative nuclear magnetic resonance spectroscopy, Journal of Agriculture and food chemistry, 63, 8551 - 8559

Elmelouky, A. Mortadi, A., Chahid, El., Elmoznine, R. (2018) Impedance spectroscopy as a tool to monitor the adsorption and removal of nitrate ions from aqueous solution using zinc aluminum chloride anionic clay, Heliyon, 4, e00536

Farmer, JT., \& Mascal, M. (2015). Platform molecules. In Clark, J., Deswarte, \& F., Introduction to chemicals from biomass, $2^{\text {nd }}$ Edition (pp.89-156). John Wiley \& Sons, Ltd.

Gorbanev, Y., O’Connell, D., \& Chechik, V. (2016) Non thermal plasma in contact with water: the origin of species, Chemistry: a European Journal, 22, 3496-3505

Grube, M., Bekers, M., Upite, D., \& Kaminska, E. (2002) E. Infrared spectra of some fructans, Spectroscopy, 16, 289-296

Higgins, HG., Stewart, CM., \& Harrington, KJ. (1961) Infrared spectra of cellulose and related polysaccharides, Journal of polymer chemistry, 51,59-84 
Horváth, HT., \& Anastas, PT. (2007) Innovations and green chemistry, Chemical Reviews, 107, 2169-2173

Ibrahim, M., Alaam, M., El-Haes, H., Jalbout, AF., \& de Leon, (2006) F. Analysis of the structure and vibrational spectra of glucose and fructose, Ecletica Quimica, 31, 15-21

Jérôme, F. (2016) Non-thermal atmospheric plasma: opportunities for the synthesis of valuable oligosaccharides from biomass, Current Opinion in Green and Sustainable Chemistry, 2, 1014

Jérôme, F., Chatel G., \& De Oliveira Vigier, K. (2016) Depolymerization of cellulose to processable glucans by non-thermal technologies, Green Chemistry, 18, 3903-3913

Kan, CW., Lam, CF., Chan, CK., \& Ng, SP. (2014) Using atmospheric pressure plasma treatment for treating grey cotton fabric, Carbohydrate Polymers, 15, 167-73

Levy DE., \& Fügedi, P. (2005) The Organic Chemistry of Sugars, CRC Press and Taylor and Francis Group

Lukes, P., Dolezalova, E., Sisrova, I., \& Clupek, M. (2014) Aqueous-phase chemistry and bactericidal effects from an air discharge plasma in contact with water, Plasma Sources Science and Technologies., 23, 015019

Machala, Z., Tarabova, B., Hensel, K., Spetlikova, E., Sikurova, L., \& Lukes, P. (2013) Formation of ROS and RNS in water electro-sprayed through transient spark discharge in air and their bactericidal effects, Plasma Process and Polymers, 10, 649-659

Mariotti, D., Patel, P., Švrček, V., \& Maguire, P. (2012) Plasma-liquid interactions at atmospheric pressure for nanomaterials synthesis and surface Engineering, Plasma Process. Polym, 9, 1074-1085 
Nastase, R., Tatibouët, J-M., \& Fourré, E. (2018) Depolymerization of inulin in the highly reactive gas phase of a non-thermal plasma at atmospheric pressure. Plasma Process and Polymers, 15, 1800067

National Research Council. Plasma processing of materials: scientific opportunities and technological challenges. (1991) Washington, DC: The National Academies Press

Ong, HC., Chen, WH., Farooq, A., Gan, YY., Lee, KT., \& Ashokkumar, V. (2019) Catalytic thermochemical conversion of biomass for biofuel production: a comprehensive review, Renewable \& Sustainable Energy Reviews, 113, 109266

Pankaj, SK., \& Keener, KM. (2017) Cold plasma: background, applications and current trends. Current Opinion in Food Science, 16, 49-52

Postek, MT., Moon, RJ., Rudie, AW., \& Bilodeau, MA. (2013) Production and Applications of Cellulose Nanomaterials, Tappi Press

Raccuia, SA., Genovese, G., Leonardi, C., Bognanni, R., Platania, C., Calderaro P., \& Melilli, MC. (2016) Fructose production by Cynara cardunculus inulin hydrolysis, Acta Horticulturae, $43,309-314$

Ropartz, D., Bodet, P-E., Przybylski, C., Gonnet, F., Daniel, R., Fer, M., Helbert, W., Bertrand, D., \& Rogniaux, H. (2011) Rapid Communication in Mass Spectrometry, 25, 2059-2070

Shainsky, N., Dobrynin, D., Ercan, U., Joshi, SG., Ji, H., Brooks, A., Fridman, G., Cho, Y., Fridman, A., \& Friedman, G. (2012) Plasma acid: water treated by dielectric barrier discharge, Plasma Process and Polymers, 10, 1-6

Sheldon, RA. (2018) Chemicals from renewable biomass: a renaissance in carbohydrate chemistry, Current Opinion in Green and Sustainable Chemistry, 14, 89-95 
517 Shiomi, N., \& Onodera, S. (1990) The 13C-NMR spectra of inulo-oligosaccharides, Agricultural Biological Chemistry., 54, 215-216

519

520

Stevens, CV., Meriggi, A., \& Booten, K. (2001) Chemical modification of inulin, a valuable renewable resource, and its industrial applications, Biomacromolecules, 2, 1-16

Sunka, P., Babicky, V., Lupek, MC., Lukes, P., Simek, M., Schmidt, J., \& Cernak, M. (1999) Generation of chemically active species by electrical discharge in water, Plasma Sources Science and Technology, 8, 258-265

Sylla-Iyarreta Veitía, S., \& Ferroud, C. (2015) New activation methods used in green chemistry for the synthesis of high added value molecules, International Journal of Energy and Environmental Engineering., 6, 37-46

Takai, O. (2008) Solution plasma processing (SPP), Pure and Applied Chemistry, 80, 20032011

Tarabova, B., Lukes, P., Janda, M., Hensel, K., Sikurova, L., \& Machala, Z. (2018) Specificity of detection methods of nitrites and ozone in aqueous soutions activated by air plasma, Plasma Process and Polymers, 15, 1800030

Tendero, C., Tixier, C., Tristant, P., Desmaison, J., \& Leprince, P. (2006) Atmospheric pressure plasmas: a review, Spectrochimica. Acta Part B, 61, 2-30

Wack, M., \& Blaschek, W. (2006) Determination of the Structure and Degree of Polymerisation of Fructans from Echinacea Purpurea Roots, Carbohydrate Research, 341, 1147-53 